\title{
Transcriptional response of Saccharomyces cerevisiae to potassium starvation
}

\author{
Ida G Anemaet and G Paul H van Heusden*
}

\begin{abstract}
Background: Ion homeostasis is essential for every cell and aberrant cation homeostasis is related to diseases like Alzheimer's disease and epilepsy. The mechanisms responsible for cation homeostasis are only partly understood. The yeast Saccharomyces cerevisiae is an excellent organism to study fundamental aspects of cation homeostasis. In this study we investigated the transcriptional response of this yeast to potassium starvation by using Serial Analysis of Gene Expression (SAGE)-tag sequencing.

Results: Comparison of transcript levels in cells grown for $60 \mathrm{~min}$ in media without potassium with those in cells grown under standard potassium concentrations showed that the mRNA levels of 105 genes were significantly $(P<0.01)$ up-regulated more than 2.0-fold during potassium starvation and the mRNA levels of 172 genes significantly down-regulated. These genes belong to several functional categories. Genes involved in stress response including HSP3O, YRO2 and TPO2 and phosphate metabolism including PHO84, PHO5 and SPL2 were highly up-regulated. Analysis of the promoter of PHO84 encoding a high affinity phosphate transporter, revealed that increased PHO84 RNA levels are caused by both increased Pho4-dependent transcription and decreased RNA turnover. In the latter process antisense transcription may be involved. Many genes involved in cell cycle control, and to a lesser extent genes involved in amino acid transport, were strongly down-regulated.
\end{abstract}

Conclusions: Our study showed that yeast cells respond to potassium starvation in a complex way and reveals a direct link between potassium homeostasis and phosphate metabolism.

Keywords: Saccharomyces cerevisiae, Cation homeostasis, SAGE tag sequencing, RNAseq, PHO84, Antisense RNA, Potassium starvation

\section{Background}

Cation homeostasis is an indispensable process for every living cell. The intracellular concentration of $\mathrm{H}^{+}, \mathrm{K}^{+}$and $\mathrm{Na}^{+}$cations must be tightly regulated because $\mathrm{H}^{+}$and $\mathrm{K}^{+}$ are involved in important processes and activities of many cellular systems. On the other hand, extreme $\mathrm{Na}^{+}$concentrations are toxic for cells. Aberrant cellular cation homeostasis is related to human neurological diseases like Alzheimer's disease [1,2] and epilepsy [3]. Furthermore, cation homeostasis is critically important for apoptosis [4] and aberrant serum potassium levels are related to diseases like hypo- and hyperkalemia and Crohn's disease. Properties of ion homeostasis in plants determine their ability to grow in environments with very low or high concentrations of salts (for review see: [5]).

\footnotetext{
* Correspondence: g.p.h.van.heusden@biology.leidenuniv.nl Institute of Biology, Leiden University, Sylviusweg 72, Leiden 2333BE, The Netherlands
}

The yeast Saccharomyces cerevisiae is an excellent model organism to study cation homeostasis (for reviews see: [6-8]). In this yeast intracellular potassium concentration is relatively stable at $200-300 \mathrm{mM}$. On the other hand, the intracellular $\mathrm{Na}^{+}$concentration is an order of magnitude lower, around $20 \mathrm{mM}$. Maintenance of high intracellular concentrations of potassium is facilitated by the generation of a membrane potential by the proton ATPase Pma1 [9] and two high affinity potassium transporters Trk1 and Trk2 $[10,11]$. Sodium ions are mainly extruded by the Ena1-5 ATP-dependent sodium-potassium transporters [12,13]. Potassium is extruded from the cells by the Nha1 and Tok1 transporters $[14,15]$. The activity of these transporters is highly regulated by several protein kinases and protein phosphatases and by protein turnover. Regulation of ion homeostasis at the transcriptional level is less well understood. Genome-wide studies mainly addressed the transcriptional response to high sodium- or 
potassium levels rather than the response to cation starvation conditions [16-19].

To further understand cation homeostasis in S. cerevisiae a number of European research groups including ours collaborate in the Translucent consortium [8]. To allow studies on the response of yeast to different concentrations of potassium, a new YNB medium containing negligible concentrations of alkali metal cations has been developed by the consortium [20]. In a recent study this medium was used to study the short-term response to potassium starvation at the transcriptional level using DNA microarrays [21]. This study showed that the lack of potassium drastically activates sulfur metabolism (mainly methionine and cysteine metabolism), triggers an oxidative stress response and activate the retrograde pathway. The expression of genes encoding ribosomal proteins and proteins involved in the cell cycle was considerably lowered. In this study, we investigated the transcriptional response to potassium starvation using Serial Analysis of Gene Expression (SAGE)tag sequencing. The expression of genes involved in several cellular processes was shown to be affected during potassium starvation including genes encoding proteins involved in stress response and phosphate metabolism. The effect of potassium starvation on the expression of PHO84 encoding an high affinity phosphate transporter was shown to be caused by an activation of the PHO84 promoter through the Pho4 transcription factor as well as at the level of RNA turnover.

\section{Results}

\section{Transcriptome analysis by SAGE tag sequencing}

To further understand the mechanisms of ion homeostasis we analyzed the effects of potassium starvation on the genome-wide transcription in S. cerevisiae. In our studies we used the Translucent YNB medium containing very low concentrations of alkali metal cations, allowing controlled addition of potassium. Exponential growing cells in four independent cultures were transferred to medium containing $50 \mathrm{mM} \mathrm{KCl}$ or lacking $\mathrm{KCl}$ and grown for $60 \mathrm{~min}$. RNA was isolated for transcriptome analysis. Recent technological developments made RNA sequencing the method of choice over analysis using DNA microarrays for such studies. We used SAGE tag sequencing allowing accurate quantification of RNA levels. The SAGE tags were aligned to a virtual tag library corresponding to all $S$. cerevisiae annotated open reading frames (www.yeastgenome. org) including $200 \mathrm{bp}$ downstream sequences. In this way, transcriptional information was obtained for 6053 loci [see Additional file 1].

Comparison of transcript levels isolated from cells grown in media without potassium with those isolated from cells grown under standard potassium concentrations showed that the mRNA levels of 105 genes were significantly $(\mathrm{P}<0.01)$ up-regulated more than 2.0 -fold during potassium starvation and the mRNA levels of 172 genes significantly down-regulated. The 25 most upregulated genes are shown in Table 1, the 25 most down-regulated genes in Table 2. Classification according to GO-term biological process using FunSpec [22] of the genes up-regulated at least 2 -fold $(\mathrm{P}<0.01)$ showed that the up-regulated genes belong to many different categories and that especially genes involved in phosphate metabolism, cytogamy and stress response are enriched in this set of genes (Table 3). In addition, genes involved carbohydrate metabolism are affected and genes subject to glucose repression like HXK1 are induced. Classification of the genes down-regulated at least 2 -fold $(\mathrm{P}<0.01)$ by potassium starvation shows a very clear enrichment of genes involved in cell cyclerelated processes. In addition genes involved in ammonia assimilation and amino acid transport are enriched in this set of genes (Table 4).

Our SAGE-tag sequencing showed that the stress response genes HSP30, TPO2 and YRO2 were highly upregulated upon potassium starvation, but due to the variation in expression in the individual cultures the effect did not meet our criteria for significance, i.e. $\mathrm{P}<$ 0.01 . By real time qRT-PCR we verified the effects of potassium starvation on these genes, using ACT1 as control. As shown in Table 5 qRT-PCR clearly showed that HSP30, TPO2 and YRO2 were strongly up-regulated upon potassium starvation in agreement with the RNAseq data. As an additional control we verified the expression of GAP1 and ALG9 by qRT-PCR. Both by RNAseq and qRT-PCR we showed that GAP1 was strongly downregulated whereas the control gene $A L G 9$ [23] was only slightly affected by potassium starvation (Table 5 ).

\section{Growth of selected deletion strains at low potassium concentrations}

An obvious question is whether the up-regulated genes are required for growth at low potassium concentrations. To this end strains deleted for the most up-regulated genes or deleted for $\mathrm{PHO} 4$ (encoding a transcription factor regulating the expression of genes involved in phosphate metabolism, see below) were spotted on plates with 50 or $0.5 \mathrm{mM} \mathrm{KCl}$. The trk1trk2 double disruptant, lacking the high affinity potassium transporters Trk1 and Trk2, was used as a control. None of the selected disruptants $(\Delta s s n 8$, $\Delta c i t 3, \Delta h s p 82, \Delta p d c 5, \Delta p h o 84, \Delta s p l 2, \Delta h s p 104, \Delta i e s 5$, $\Delta$ pho4) showed an aberrant growth at $0.5 \mathrm{mM} \mathrm{KCl}$, whereas the trk1trk2 mutant (BYT12) did not grow at this $\mathrm{KCl}$ concentration (Figure 1). These results indicate that the most up-regulated genes are not by themselves required for growth at low potassium concentrations. To study the survival of the tested disruption strains at low potassium conditions, these strains were spotted on a plate lacking potassium and after six days the cells were 
Table 1 The 25 most up-regulated genes after 60 min of potassium starvation $(P<0.01)$

\begin{tabular}{|c|c|c|c|c|c|}
\hline Annotation & Description & $\begin{array}{l}\text { RNA level } 50 \mathrm{mM} \\
\text { (reads per million) } \\
( \pm S D ; n=4)\end{array}$ & $\begin{array}{l}\text { RNA level } 0 \mathrm{mM} \\
\text { (reads per million) } \\
( \pm S D ; n=4)\end{array}$ & $\begin{array}{l}\text { Fold-change } \\
(0 \mathrm{mM} / 50 \mathrm{mM})\end{array}$ & P-value \\
\hline SSN8 & Cyclin-like component of the RNA polymerase II holoenzyme & $5.2 \pm 2.5$ & $71 \pm 20$ & 13.7 & 0.001 \\
\hline YER138W-A & Putative protein of unknown function & $2.3 \pm 2.3$ & $29 \pm 13$ & 12.4 & 0.007 \\
\hline CIT3 & Dual specificity mitochondrial citrate and methylcitrate synthase & $6.6 \pm 3.2$ & $75 \pm 26$ & 11.4 & 0.002 \\
\hline HSP82 & Hsp90 chaperone; redundant in function with $\mathrm{Hsc} 82 \mathrm{p}$ & $175 \pm 52$ & $1845 \pm 333$ & 10.6 & 0.000 \\
\hline PDC5 & Minor isoform of pyruvate decarboxylase & $21 \pm 6$ & $219 \pm 43$ & 10.5 & 0.000 \\
\hline PHO84 & High-affinity inorganic phosphate (Pi) transporter & $50 \pm 27$ & $516 \pm 214$ & 10.3 & 0.005 \\
\hline YBR085C-A & Protein of unknown function & $46 \pm 19$ & $443 \pm 180$ & 9.6 & 0.005 \\
\hline YGR161W-C & Putative protein of unknown function & $7.6 \pm 3.4$ & $72 \pm 26$ & 9.5 & 0.002 \\
\hline YIL082W-A & Retrotransposon TYA Gag and TYB Pol genes & $1.2 \pm 0.5$ & $9.8 \pm 2.7$ & 8.1 & 0.001 \\
\hline SPL2 & Protein with similarity to cyclin-dependent kinase inhibitors & $31 \pm 5$ & $224 \pm 70$ & 7.3 & 0.001 \\
\hline MCM10 & Essential chromatin-associated protein & $2.1 \pm 0.6$ & $14 \pm 4$ & 6.9 & 0.001 \\
\hline HSP104 & Disaggregase & $107 \pm 50$ & $718 \pm 287$ & 6.7 & 0.006 \\
\hline IES5 & $\begin{array}{l}\text { Protein that associates with the Ino80 chromatin remodeling } \\
\text { complex }\end{array}$ & $31 \pm 10$ & $186 \pm 66$ & 6.1 & 0.003 \\
\hline PHM6 & Protein of unknown function & $11 \pm 6$ & $66 \pm 25$ & 5.9 & 0.005 \\
\hline YNL146W & Putative protein of unknown function & $3.2 \pm 1.6$ & $19 \pm 6$ & 5.8 & 0.003 \\
\hline HSP42 & Small heat shock protein with chaperone activity & $57 \pm 25$ & $331 \pm 95$ & 5.8 & 0.001 \\
\hline ECL1 & Protein of unknown function & $99 \pm 49$ & $549 \pm 169$ & 5.5 & 0.002 \\
\hline STI1 & Hsp90 cochaperone & $157 \pm 51$ & $805 \pm 230$ & 5.1 & 0.002 \\
\hline ARE2 & Acyl-CoA:sterol acyltransferase & $4.7 \pm 1.2$ & $24 \pm 10$ & 5.1 & 0.010 \\
\hline HXK1 & Hexokinase isoenzyme 1 & $202 \pm 70$ & $1027 \pm 373$ & 5.1 & 0.005 \\
\hline FUS1 & Membrane protein localized to the shmoo tip & $22 \pm 13$ & $107 \pm 32$ & 4.9 & 0.002 \\
\hline SSA3 & ATPase involved in protein folding and the response to stress & $7.2 \pm 1.8$ & $35 \pm 15$ & 4.9 & 0.010 \\
\hline ESC2 & Sumo-like domain protein & $2.4 \pm 1.2$ & $11 \pm 5$ & 4.8 & 0.009 \\
\hline MET28 & $\begin{array}{l}\text { bZIP transcriptional activator in the Cbf1p-Met } 4 p-M e t 28 p \\
\text { complex }\end{array}$ & $11 \pm 4$ & $51 \pm 20$ & 4.8 & 0.008 \\
\hline YBLO05W-B & Retrotransposon TYA Gag and TYB Pol genes & $1495 \pm 714$ & $7106 \pm 1942$ & 4.7 & 0.002 \\
\hline
\end{tabular}

transferred to plates with $50 \mathrm{mM} \mathrm{KCl}$. No significant differences in growth compared to the wild type strain were observed, except for the trk1 trk2 strain (data not shown).

\section{Promoter analysis}

Using the information available in the Yeastract database (www.yeastract.com) it became clear that many different transcription factors are associated with the up-regulated genes. This suggests that the transcriptional response to potassium starvation is not linked to the activation of a single transcription factor. Two of the up-regulated genes related to stress-response, i.e. YRO2 and TPO2, are also up-regulated upon weak acid stress [24]. The latter upregulation is dependent on the transcription factor Haa1. However, in a $\Delta$ haal mutant $Y R O 2$ is still highly upregulated upon potassium starvation (RM Läkamp and GPH van Heusden, unpublished results) making a role of
Haal in the response to potassium starvation less likely. To further analyze the regulation of YRO2 and TPO2 the promoter sequences were placed upstream of the bacterial $\beta$ galactosidase gene in plasmid pRUL302 and introduced in yeast strain BY4741. The resulting strains were cultivated in the presence of $50 \mathrm{mM} \mathrm{KCl}$ till mid-exponential growth, transferred to media with $50 \mathrm{mM} \mathrm{KCl}$ or to media lacking $\mathrm{KCl}$ and grown for $60 \mathrm{~min}$. Then, cells were isolated and ß-galactosidase activity was determined. Using 510 bp of sequences of the TPO2 promoter or $2141 \mathrm{bp}$ of sequences of the YRO2 promoter we found an only 1.3-fold or 2.1fold, respectively, increase in $\beta$-galactosidase activity upon potassium starvation, whereas RNAseq showed 4.6-fold $(\mathrm{P}=0.025)$ and 23 -fold $(\mathrm{P}=0.075)$, respectively, increase in mRNA level, suggesting that also other mechanisms than activation of the promoter are involved in the expression of YRO2 and TPO2 during potassium starvation. 
Table 2 The 25 most down-regulated genes after 60 min of potassium starvation $(P<0.01)$

\begin{tabular}{|c|c|c|c|c|c|}
\hline Annotation & Description & $\begin{array}{l}\text { RNA level } 50 \mathrm{mM} \\
\text { (reads per million) } \\
( \pm S D ; n=4)\end{array}$ & $\begin{array}{l}\text { RNA level } 0 \mathrm{mM} \\
\text { (reads per million) } \\
( \pm S D ; n=4)\end{array}$ & $\begin{array}{l}\text { Fold-change } \\
(50 \mathrm{mM} / 0 \mathrm{mM})\end{array}$ & P-value \\
\hline YIL171W-A & Dubious open reading frame & $0.6 \pm 0.2$ & $0.0 \pm 0.0$ & - & 0.001 \\
\hline RER1 & Protein involved in retention of membrane proteins & $0.5 \pm 0.2$ & $0.0 \pm 0.0$ & - & 0.001 \\
\hline CLB6 & B-type cyclin involved in DNA replication during $S$ phase & $23 \pm 10$ & $0.3 \pm 0.4$ & 71.2 & 0.004 \\
\hline TOS6 & Glycosylphosphatidylinositol-dependent cell wall protein & $395 \pm 42$ & $12 \pm 9$ & 32.5 & 0.000 \\
\hline POL30 & Proliferating cell nuclear antigen & $166 \pm 46$ & $5.7 \pm 4.0$ & 29.1 & 0.000 \\
\hline PCL1 & Cyclin, interacts with cyclin-dependent kinase Pho85p & $100 \pm 30$ & $4.1 \pm 3.4$ & 24.6 & 0.001 \\
\hline TOS4 & $\begin{array}{l}\text { Putative transcription factor, contains Forkhead Associated } \\
\text { domain }\end{array}$ & $54 \pm 15$ & $2.5 \pm 2.4$ & 21.3 & 0.001 \\
\hline KCC4 & $\begin{array}{l}\text { Protein kinase of the bud neck involved in the septin } \\
\text { checkpoint }\end{array}$ & $42 \pm 14$ & $2.1 \pm 1.4$ & 20.3 & 0.001 \\
\hline YMR230W-A & Putative protein of unknown function & $23 \pm 11$ & $1.1 \pm 1.0$ & 20.1 & 0.007 \\
\hline YOX1 & Homeobox transcriptional repressor & $71 \pm 21$ & $4.1 \pm 3.1$ & 17.2 & 0.001 \\
\hline HTA1 & Histone $\mathrm{H} 2 \mathrm{~A}$ & $1248 \pm 392$ & $74 \pm 31$ & 17.0 & 0.001 \\
\hline CDC45 & DNA replication initiation factor & $27 \pm 9$ & $1.9 \pm 1.3$ & 14.1 & 0.002 \\
\hline SWE1 & Protein kinase that regulates the $\mathrm{G} 2 / \mathrm{M}$ transition & $81 \pm 35$ & $6.8 \pm 4.7$ & 11.9 & 0.006 \\
\hline CDC21 & Thymidylate synthase & $98 \pm 34$ & $8.3 \pm 5.9$ & 11.8 & 0.002 \\
\hline ALG14 & Component of UDP-GICNAc transferase & $76 \pm 26$ & $6.7 \pm 4.6$ & 11.4 & 0.002 \\
\hline YIG1 & Protein that interacts with glycerol 3-phosphatase & $1.5 \pm 0.5$ & $0.1 \pm 0.3$ & 10.7 & 0.003 \\
\hline MCD1 & Essential alpha-kleisin subunit of the cohesin complex & $87 \pm 30$ & $8.4 \pm 5.2$ & 10.4 & 0.002 \\
\hline RPL18B & Ribosomal 605 subunit protein L18B & $774 \pm 132$ & $75 \pm 13$ & 10.4 & 0.000 \\
\hline LSM4 & Lsm (Like Sm) protein & $0.9 \pm 0.2$ & $0.1 \pm 0.2$ & 10.2 & 0.001 \\
\hline GAP1 & General amino acid permease & $146 \pm 18$ & $15 \pm 6$ & 9.6 & 0.000 \\
\hline YER088C-A & Dubious open reading frame & $24 \pm 5$ & $2.6 \pm 1.8$ & 9.4 & 0.000 \\
\hline YLR413W & Putative protein of unknown function & $207 \pm 58$ & $22 \pm 11$ & 9.4 & 0.001 \\
\hline TOS2 & $\begin{array}{l}\text { Protein involved in localization of Cdc } 24 p \text { to the site of bud } \\
\text { growth }\end{array}$ & $16 \pm 1$ & $1.7 \pm 1.5$ & 9.2 & 0.000 \\
\hline PMI40 & Mannose-6-phosphate isomerase & $361 \pm 96$ & $40 \pm 29$ & 9.1 & 0.001 \\
\hline KIP1 & Kinesin-related motor protein & $21 \pm 7$ & $2.3 \pm 1.6$ & 8.9 & 0.002 \\
\hline
\end{tabular}

Regulation of PHO84 by the transcription factor Pho4 Our RNAseq data reveal that genes involved in phosphate metabolism are well represented in the set of genes that were significantly up-regulated. Many of these genes, including PHO84, are strongly regulated in response to external phosphate concentrations (for review see: [25]). The transcription factor Pho4 translocates into the nucleus at low phosphate concentrations and plays a prominent role in activation of PHO84 expression [26]. To investigate the involvement of Pho4 in the activation of the PHO84 promoter during potassium starvation we inserted $600 \mathrm{bp}$ promoter sequences upstream of the $B$ galactosidase gene in plasmid pRUL302 and introduced the resulting plasmid in BY4741 and the $\Delta$ pho4 disruptant in the BY4741 background (each containing the pRS313 plasmid). The resulting strains were cultivated as described above to determine the effect of potassium starvation on the PHO84 promoter. As shown in Table 6, in the wild type background (BY4741) there is a clear activation of the PHO84 promoter, whereas in the $\Delta$ pho4 strain hardly any activity can be detected, both after cultivation at $50 \mathrm{mM}$ and $0 \mathrm{mM} \mathrm{KCl}$. Introduction of an intact copy of PHO4 (pRS313[PHO4]) in the wild type background gives a stimulation of the $\mathrm{PHO} 84$ promoter, both at 50 and $0 \mathrm{mM} \mathrm{KCl}$. Introduction of an intact copy of PHO4 (pRS313[PHO4]) in the $\Delta$ pho4 strain restores and activates the $\mathrm{PHO} 84$ promoter. These results indicate that the Pho4 transcription factor is required for the expression of $\mathrm{PHO} 84$ at low potassium concentrations.

\section{Promoter replacement}

To further investigate the regulation of gene expression during potassium starvation we replaced the promoter sequences of a number of genes (HSP30, TPO2, YRO2, PHO84 and ALG9) by the CYC1 promoter. This promoter is most likely not influenced by potassium starvation as 
Table 3 Functional analysis using FunSpec [22] of genes up-regulated at least 2 -fold $(P<0.01)$ during potassium starvation

\begin{tabular}{|c|c|c|c|c|}
\hline Category & $\begin{array}{l}\text { p-value } \\
\left(\times 10^{-3}\right)\end{array}$ & In category from cluster & & $f^{a}$ \\
\hline $\begin{array}{l}\text { polyphosphate metabolic process } \\
\text { [GO:0006797] }\end{array}$ & 0.19 & VTC2 VTC4 PHO84 & 3 & 8 \\
\hline cytogamy [GO:0000755] & 0.19 & FUS1 FIG 2 STE2 & 3 & 8 \\
\hline response to stress [GO:0006950] & 0.52 & SSA3 HSP26 AAD4 HSP42 MDJ1 POG1 HSP104 ST11 HSP82 & 9 & 152 \\
\hline budding cell bud growth [GO:0007117] & 2.46 & ROM1 NAP1 REH1 & 3 & 18 \\
\hline $\begin{array}{l}\text { carbohydrate metabolic process } \\
\text { [GO:0005975] }\end{array}$ & 3.18 & GLC3 HXK1 PGM3 GLC8 ZWF1 SOL1 & 6 & 94 \\
\hline 'de novo' protein folding [GO:0006458] & 3.40 & MDJ1 HSP82 & 2 & 6 \\
\hline biological_process unknown [GO:0008150] & 3.70 & $\begin{array}{l}\text { EDS1 YBR053C YBR085C-A PCS60 RTN2 PHM6 IES5 YER138W-A TMT1 YGR127W ECL1 } \\
\text { YGR161W-C HUA1 AIM17 YIL102C-A IKS1 YJL127C-B YKL023W TTI1 YKR075C YLR149C } \\
\text { YLR271W CMC4 PGM3 YNL058C YNL146W YNR014W AIM41 YOR289W UIP4 }\end{array}$ & 30 & 1203 \\
\hline NADPH regeneration [GO:0006740] & 4.72 & IDP3 ZWF1 & 2 & 7 \\
\hline cell adhesion [GO:0007155] & 4.72 & FIG 2 SAG1 & 2 & 7 \\
\hline glucose metabolic process [GO:0006006] & 5.06 & HXK1 PGM3 ZWF1 & 3 & 23 \\
\hline $\begin{array}{l}\text { branched chain family amino acid catabolic } \\
\text { process [GO:0009083] }\end{array}$ & 7.93 & BAT2 PDC5 & 2 & 9 \\
\hline $\begin{array}{l}\text { re-entry into mitotic cell cycle after } \\
\text { pheromone arrest [GO:0000321] }\end{array}$ & 7.93 & FAR7 POG1 & 2 & 9 \\
\hline $\begin{array}{l}\text { vacuole fusion, non-autophagic } \\
\text { [GO:0042144] }\end{array}$ & 9.77 & SWF1 VTC2 VTC4 & 3 & 29 \\
\hline $\begin{array}{l}\text { deadenylation-dependent decapping of } \\
\text { nuclear-transcribed mRNA [GO:0000290] }\end{array}$ & 9.81 & EDC2 DCS2 & 2 & 10 \\
\hline microautophagy [GO:0016237] & 9.81 & VTC2 VTC4 & 2 & 10 \\
\hline
\end{tabular}

$\mathrm{a}, \mathrm{k}$ : number of genes from the input cluster in given category; f: number of genes total in given category.

the levels of CYC1 RNA were hardly changed (1.2-fold lower levels after potassium starvation). The resulting strains were cultivated as above and RNA was isolated. Gene expression was determined by qRT-PCR using $A C T 1$ as a reference gene. In this way we found the following effects of potassium starvation on the RNA levels: HSP30, 0.9- and 1.3-fold increase in two independent experiments; TPO2, 0.8- and 2.2-fold increase; YRO2, 5.3and 3.5-fold decrease; PHO84, 6.8- and 8.6-fold increase; ALG9 (reference gene), 1.0- and 1.2-fold increase. These observations show that especially for $\mathrm{PHO} 4$ other regulatory aspects are involved besides activation of the promoter. Surprisingly, the levels of YRO2 RNA are reduced at $0 \mathrm{mM} \mathrm{KCl}$.

\section{Antisense transcription}

Several studies have shown that PHO84 is also transcribed in the opposite direction yielding antisense RNA $[27,28]$. SAGE tag sequencing is able to identify antisense transcripts [29,30]. This is illustrated for PHO84 in Figure 2A. Alignment of the sequenced tags to the complementary strand of the $S$. cerevisiae open reading frames (+ 200 bp downstream sequences) reveals potential antisense transcripts corresponding to 5665 loci [see Additional file 2]. The total number of tags aligning to the complementary strand is 4 to 14 percent of the total number of tags aligning to the coding strand. Comparison of the antisense transcript levels in cells grown in medium without potassium with the levels in cells grown under standard potassium concentrations shows that antisense transcription of 34 genes was significantly $(\mathrm{P}<0.01)$ up-regulated more than 2 -fold, whereas antisense transcripts of 76 genes were significantly downregulated [see Additional file 3]. Several tags aligned to the complementary strand of PHO84. Almost all tags were found at a higher level using RNA isolated from cells grown at $0 \mathrm{mM} \mathrm{KCl}$ compared to cells grown at $50 \mathrm{mM} \mathrm{KCl}$ [see Additional file 3]. The total number of tags corresponding to antisense transcripts of the PHO84 gene is 8.7 -fold $(\mathrm{P}=0.07)$ increased after potassium starvation.

Antisense PHO84 transcripts were further analyzed by RT-PCR using strand specific primers. cDNA synthesis using a primer specific for antisense RNA (primer AScDNA, Figure 2B) yields cDNA dependent on antisense transcripts. Using primers AS-PCR-Fw and AS-PCR-Rv (Figure 2B) this cDNA can be detected by PCR. As shown in Figure 2C (lanes 3 and 4) the expected PCR fragment was found. This band was not found when primer SEcDNA (Figure 2B, lane 5 and 6) was used as primer for 
Table 4 Functional analysis using FunSpec [22] of genes down-regulated at least 2 -fold $(P<0.01)$ during potassium starvation

\begin{tabular}{|c|c|c|c|c|}
\hline Category & $\begin{array}{l}\text { p-value } \\
\left(\mathrm{x} 10^{-3}\right)\end{array}$ & In category from cluster & $k^{a}$ & $f^{a}$ \\
\hline cell division [GO:0051301] & 0.007 & $\begin{array}{l}\text { LTE1 KIP1 HSL7 KCC4 MCD1 UBC9 PDS1 SPC25 CLB1 CLB6 SWE1 PCL1 SGO1 } \\
\text { NUD1 CLN2 CLB5 KAR3 }\end{array}$ & 17 & 190 \\
\hline $\begin{array}{l}\text { regulation of cyclin-dependent protein kinase activity } \\
\text { [GO:0000079] }\end{array}$ & 0.008 & CLB1 CLB6 SWE1 PCL1 CLN2 CLB5 & 6 & 20 \\
\hline cell cycle [GO:0007049] & 0.019 & $\begin{array}{l}\text { LTE1 KIP1 HSL7 KCC4 MCD1 PSA1 UBC9 PDS1 SPC25 CLB1 CLB6 SWE1 SLD2 } \\
\text { CDC45 YOX1 TOF1 PCL1 SGO1 NUD1 CLN2 CLB5 KAR3 }\end{array}$ & 22 & 316 \\
\hline mitosis [GO:0007067] & 0.15 & LTE1 KIP1 HSL7 MCD1 UBC9 PDS1 SPC25 CLB1 SWE1 SGO1 NUD1 KAR3 & 12 & 132 \\
\hline ammonia assimilation cycle [GO:0019676] & 0.16 & GAP1 PUT4 GDH1 & 3 & 5 \\
\hline amino acid transmembrane transport [GO:0003333] & 0.31 & GNP1 HNM1 GAP1 BIO5 PUT4 & 5 & 24 \\
\hline $\begin{array}{l}\text { double-strand break repair via break-induced replication } \\
\text { [GO:0000727] }\end{array}$ & 0.46 & RDH54 SLD5 SLD2 CDC45 CTF4 & 5 & 26 \\
\hline DNA replication [GO:0006260] & 0.66 & POL12 POL30 SLD5 SLD2 CDC45 TOF1 RFA2 CTF4 & 8 & 75 \\
\hline G2/M transition of mitotic cell cycle [GO:0000086] & 0.67 & HSL7 UBC9 CLB1 SWE1 CLB5 & 5 & 28 \\
\hline positive regulation of DNA replication [GO:0045740] & 0.67 & CLB6 CLB5 & 2 & 2 \\
\hline GDP-mannose biosynthetic process [GO:0009298] & 0.67 & PSA1 PMI40 & 2 & 2 \\
\hline meiotic mismatch repair [GO:0000710] & 0.87 & POL30 MSH6 PMS1 & 3 & 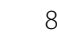 \\
\hline budding cell bud growth [GO:0007117] & 1.00 & KCC4 GIN4 TOS2 DFG5 & 4 & 18 \\
\hline 'de novo' IMP biosynthetic process [GO:0006189] & 1.28 & ADE17 ADE4 ADE2 & 3 & 9 \\
\hline microtubule nucleation [GO:0007020] & 1.84 & SPC25 SPC97 STU2 SPC98 & 4 & 21 \\
\hline gamma-aminobutyric acid transport [GO:0015812] & 1.97 & GAP1 PUT4 & 2 & 3 \\
\hline $\begin{array}{l}\text { regulation of S phase of mitotic cell cycle } \\
\text { [GO:0007090] }\end{array}$ & 1.97 & CLB6 CLB5 & 2 & 3 \\
\hline mitotic sister chromatid cohesion [GO:0007064] & 3.08 & POL30 TOF1 CTF4 KAR3 & 4 & 24 \\
\hline $\begin{array}{l}\text { cell wall mannoprotein biosynthetic process } \\
\text { [GO:0000032] }\end{array}$ & 3.16 & PSA1 PMI40 KTR1 & 3 & 12 \\
\hline glycine metabolic process [GO:0006544] & 3.87 & SHM2 GCV2 & 2 & 4 \\
\hline septin checkpoint [GO:0000135] & 3.87 & KCC4 GIN4 & 2 & 4 \\
\hline amino acid transport [GO:0006865] & 4.30 & GNP1 HNM1 GAP1 BIO5 PUT4 & 5 & 42 \\
\hline response to DNA damage stimulus [GO:0006974] & 4.92 & RDH54 POL30 MCD1 DUN1 MSH6 HTA1 SRS2 TOS4 OGG1 PMS1 TOF1 SMC5 & 12 & 197 \\
\hline telomere maintenance via telomerase [GO:0007004] & 6.17 & EST1 RAP1 RFA2 & 3 & 15 \\
\hline DNA repair [GO:0006281] & 7.71 & RDH54 POL30 MSH6 HTA1 SRS2 OGG1 PMS1 TOF1 RFA2 SMC5 CTF4 & 11 & 183 \\
\hline $\begin{array}{l}\text { negative regulation of transcription from RNA } \\
\text { polymerase II promoter, global [GO:0045816] }\end{array}$ & 9.34 & HTB1 HTA1 & 2 & 6 \\
\hline regulation of mitotic cell cycle [GO:0007346] & 9.34 & SMI1 YOX1 & 2 & 6 \\
\hline premeiotic DNA replication [GO:0006279] & 9.34 & CLB6 CLB5 & 2 & 6 \\
\hline replication fork protection [GO:0048478] & 9.34 & DUN1 TOF1 & 2 & 6 \\
\hline
\end{tabular}

$\mathrm{a}, \mathrm{k}$ : number of genes from the input cluster in given category; f: number of genes total in given category.

cDNA synthesis, which generates cDNA corresponding to sense transcripts. These results indicate that antisense PHO84 RNA can be detected RT-PCR, in agreement with our RNAseq experiments and previous studies.

\section{Discussion and conclusion}

The yeast $S$. cerevisiae is an excellent organism to study fundamental aspects of cation homeostasis. Although many components involved in the maintenance of cation homeostasis in this yeast have already been revealed, still many aspects remain unclear. Understanding the response of yeast cells to potassium starvation is essential for understanding the mechanisms involved in cation homeostasis. Therefore, the Translucent consortium developed a new medium, based on the widely used YNBmedium, containing negligible amounts of alkali metal cations [20]. This medium allowed potassium starvation studies. Studies have been conducted to address effects 
Table 5 Analysis of the effect of potassium starvation by qRT-PCR

\begin{tabular}{llll}
\hline Gene & \multicolumn{2}{l}{ Fold change qRT-PCR } & $\begin{array}{l}\text { Fold change } \\
\text { RNAseq }\end{array}$ \\
\cline { 2 - 3 } & Experiment 1 & Experiment 2 & \\
\hline TPO2 & 4.5 & 5.1 & $4.6(P=0.025)$ \\
HSP30 & 11.1 & 18.0 & $19.7(P=0.011)$ \\
YRO2 & 10.4 & 40.9 & $23.1(P=0.075)$ \\
GAP1 & $-12.9^{\text {a }}$ & -23.7 & $-9.6(P<0.001)$ \\
ALG9 & 1.2 & 1.7 & -1.25 \\
\hline
\end{tabular}

a, down-regulation is indicated with ' - '.

at the transcriptional [21] and proteomic level [31]. Using DNA microarrays it was shown that the lack of potassium affects the expression of more than one thousand genes including a strong activation of genes involved in sulfur metabolism, oxidative stress response and the retrograde pathway and a reduced expression of genes involved in ribosome biogenesis and cell cycle control. At the protein level a general decrease in protein content and an increased level of stress-related proteins were found.

In this study we used SAGE-tag sequencing to analyze the transcriptional response of $S$. cerevisiae to potassium starvation. We used four independent biological replicates and for reasons unknown the variation between these replicates is somewhat larger than expected. Despite this variation, similarly to the study with DNA microarrays we found a very pronounced effect of potassium starvation on gene expression and the expression of genes belonging to many functional categories was affected. The power of SAGE-tag sequencing is that also lowly expressed genes can be analyzed. Therefore, we were able to obtain information on the expression of 6053 different loci, much higher than what can be achieved by DNA microarrays. Both in this study and in the study with DNA microarrays a strong up-regulation of genes involved in stress response and a strong down-regulation of genes involved in various aspects of cell cycle control were found. Although the overall trend found in this and the previous study is very similar, also quantitative differences were found. One of the examples is the effect on the expression of genes involved in sulfur metabolism. In the previous study after $60 \mathrm{~min}$ of potassium starvation SUL2, MUP3, MET3, STR3, MET14, MET28, SER3 and MET10 were all upregulated more than 4-fold. For these genes we also found up-regulation, although much less pronounced.

The effect of potassium starvation on the S. cerevisiae transcriptome has also been investigated using chemostat cultures [32]. In that study, only a limited number of genes were strongly affected by potassium limitation, and the great majority of these were genes known to be involved in nitrogen metabolism. Genes encoding ammonium ion and amino acid transporters (MEP2 and GAP1) were down-regulated 30-fold and virtually all other nitrogen catabolite-repressed genes were strongly

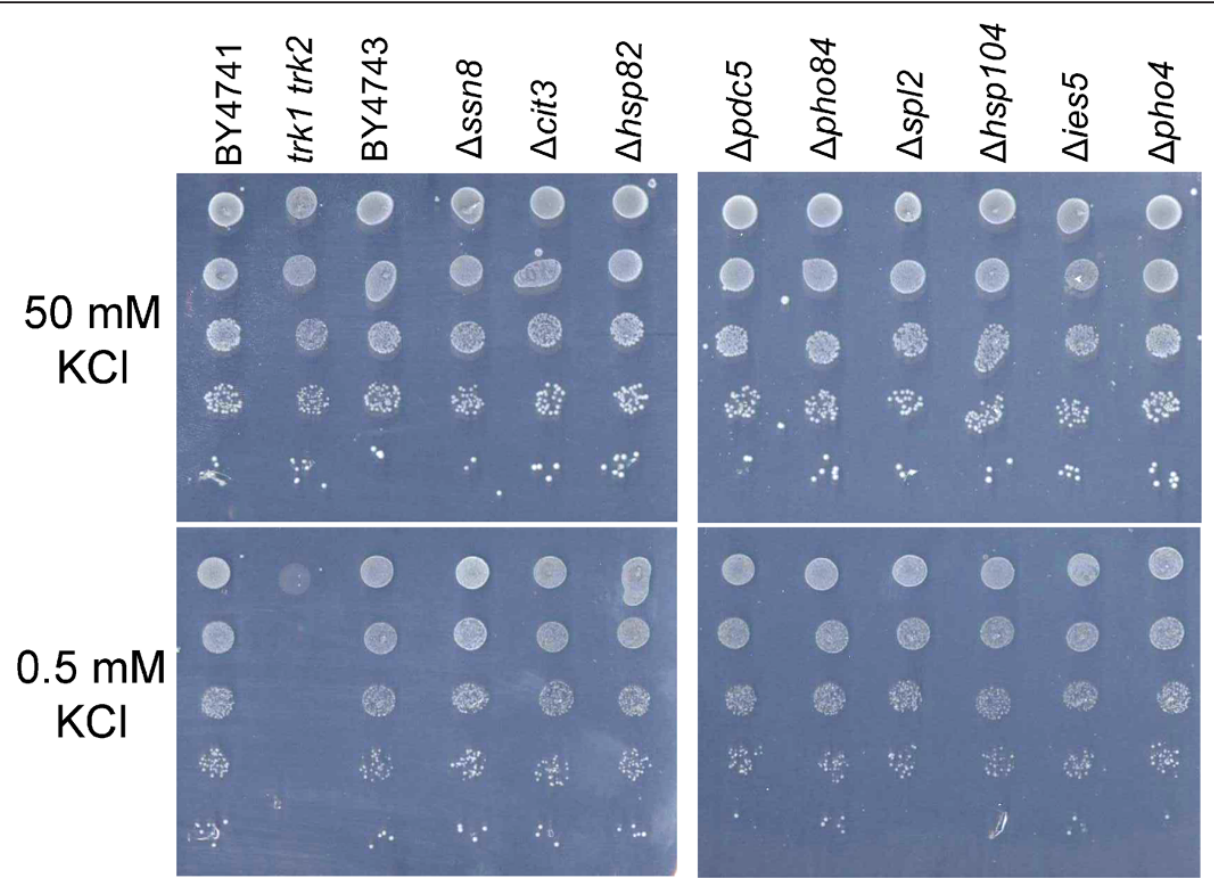

Figure 1 Growth at 50 and $0.5 \mathrm{mM} \mathrm{KCl}$ of deletion strains lacking genes highly up-regulated during potassium starvation or lacking PHO4. Ten-fold serial dilutions of the indicated strains are spotted on Translucent YNB plates supplemented with histidine, methionine, leucine and uracil containing 50 or $0.5 \mathrm{mM} \mathrm{KCl}$. Plates were incubated for 3 days at $30^{\circ} \mathrm{C}$. 
Table 6 Role of Pho4 in the transcriptional regulation of PHO84 during potassium starvation

\begin{tabular}{|c|c|c|c|c|}
\hline \multirow[t]{2}{*}{ Strain } & \multirow[t]{2}{*}{ Plasmid } & \multicolumn{2}{|c|}{$\begin{array}{l}\text { B-galactosidase activity } \\
\text { (arbitrary units) }\end{array}$} & \multirow[t]{2}{*}{$\begin{array}{l}\text { Fold change } \\
(0 \mathrm{mM} / 50 \mathrm{mM})\end{array}$} \\
\hline & & $50 \mathrm{mM} \mathrm{KCl}$ & $0 \mathrm{mM} \mathrm{KCl}$ & \\
\hline BY4741 & pRS313 & 0.13 & 0.56 & 4.1 \\
\hline BY4741 & pRS313[PHO4] & 2.36 & 3.34 & 1.4 \\
\hline$\Delta$ pho4 & pRS313 & 0.00 & 0.00 & - \\
\hline$\Delta$ pho4 & pRS313[PHO4] & 1.41 & 2.84 & 2.0 \\
\hline
\end{tabular}

Results of a typical experiment are given. In each experiment two independent transformants were analyzed, the average is shown.

down-regulated as well. SPS-regulated amino acid permeases were strongly up-regulated. In our study we also found a strong down-regulation of GAP1 and MEP2 (9.6 and 7.4-fold, respectively). On the other hand, in our study genes encoding amino acid permeases were downregulated instead of up-regulated (GNP1 5.5-fold, DIP1 2.6-fold, TAT2 1.1-fold, AGP1 9.8-fold, PTR2 3.0-fold, $B A P 2$ 3.5-fold and MUP1 1.3-fold-down-regulated, see Additional file 1). In this respect it has to be mentioned that the physiological state of yeast cells in chemostat cultures can be greatly different from that of cells in shake flask cultures and that different media were used in the two studies.

Potassium homeostasis is regulated by a complex interplay between transporters and regulatory proteins. Many proteins have been identified that bind to the various $S$. cerevisiae ion transports [8] (www.yeastgenome.org). The function of most of these interactions is still unknown and a role in the regulation of the ion transporters is imaginable. In Figure 3 a number of S. cerevisiae ion transporters and their binding partners is shown and the effect of potassium starvation on their transcript levels is indicated in a color scale, with down-regulation in green and upregulation in red. It is clear that the RNA levels of some binding partners are increased and of some binding partners decreased. For example, HSP30, encoding a Nha1 binding partner, and $A R R 3$, encoding an Ena2 binding partners are strongly up-regulated. The RNA levels of many, but not all, of the binding partners of the Nhx1 transporter are decreased. However, the significance of these observations still has to be shown.

Identification of transcription factors involved in the regulation of gene expression during potassium starvation is very complex. Using the information on transcription factor associations in the Yeastract database (www.yeastract.com) many different transcription factors were found associated with the up- or down-regulated genes. The transcription factor Pho4 may participate in gene regulation during potassium starvation. This transcription factor is found to be associated with seven of the 25 most up-regulated genes, i.e. ARE2, FUS1, HSP104, PHM6, PHO84, SPL2 and YNL146W (www. yeastract.com). Deletion of $\mathrm{PHO} 4$ strongly affected the activity of PHO84 promoter. However, other transcription factors are most likely be involved as well. In addition, RNA turnover is important. After replacement of the PHO84 promoter by the CYC1 promoter PHO84 RNA levels are still approximately five-fold increased.

In this study as well as in the study using DNA microarrays [21] a strong induction if genes involved in phosphate metabolism, including PHO84, was found. Thus, despite the presence of phosphate in the medium, these genes are not repressed, when potassium is absent. The transcription factor Pho4 plays a key role in the regulation of these genes. The subcellular localization of this transcription factor is regulated via phosphorylation by

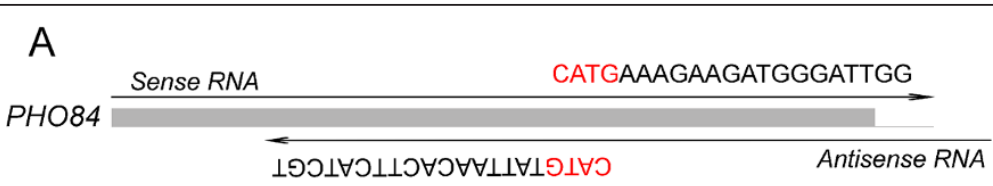

B
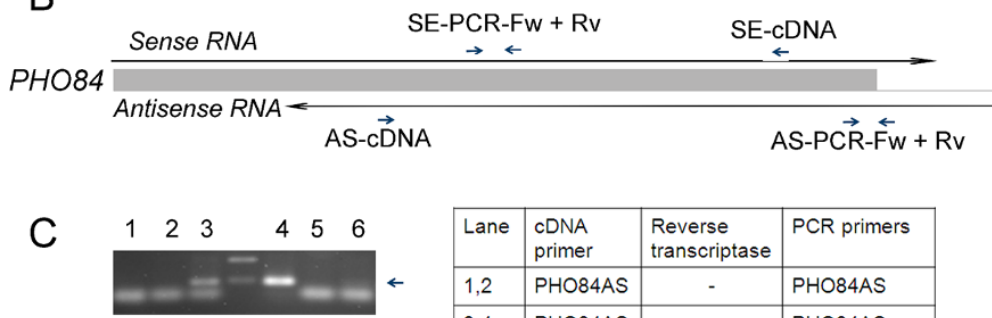

\begin{tabular}{|l|l|c|l|}
\hline Lane & $\begin{array}{l}\text { cDNA } \\
\text { primer }\end{array}$ & $\begin{array}{l}\text { Reverse } \\
\text { transcriptase }\end{array}$ & PCR primers \\
\hline 1,2 & PHO84AS & - & PHO84AS \\
\hline 3,4 & PHO84AS & + & PHO84AS \\
\hline 5,6 & PHO84SE & + & PHO84AS \\
\hline
\end{tabular}

Figure 2 Antisense transcription of PHO84. A, scheme showing the position of SAGE tags corresponding to sense and antisense transcripts. B, primers used to detect PHO84 antisense transcripts. C. Detection of antisense transcripts using strand specific CDNA synthesis and PCR. RNA was isolated from cells grown for 60 min in Translucent YNB medium lacking potassium. Arrow indicates the position of the expected PCR fragment. 


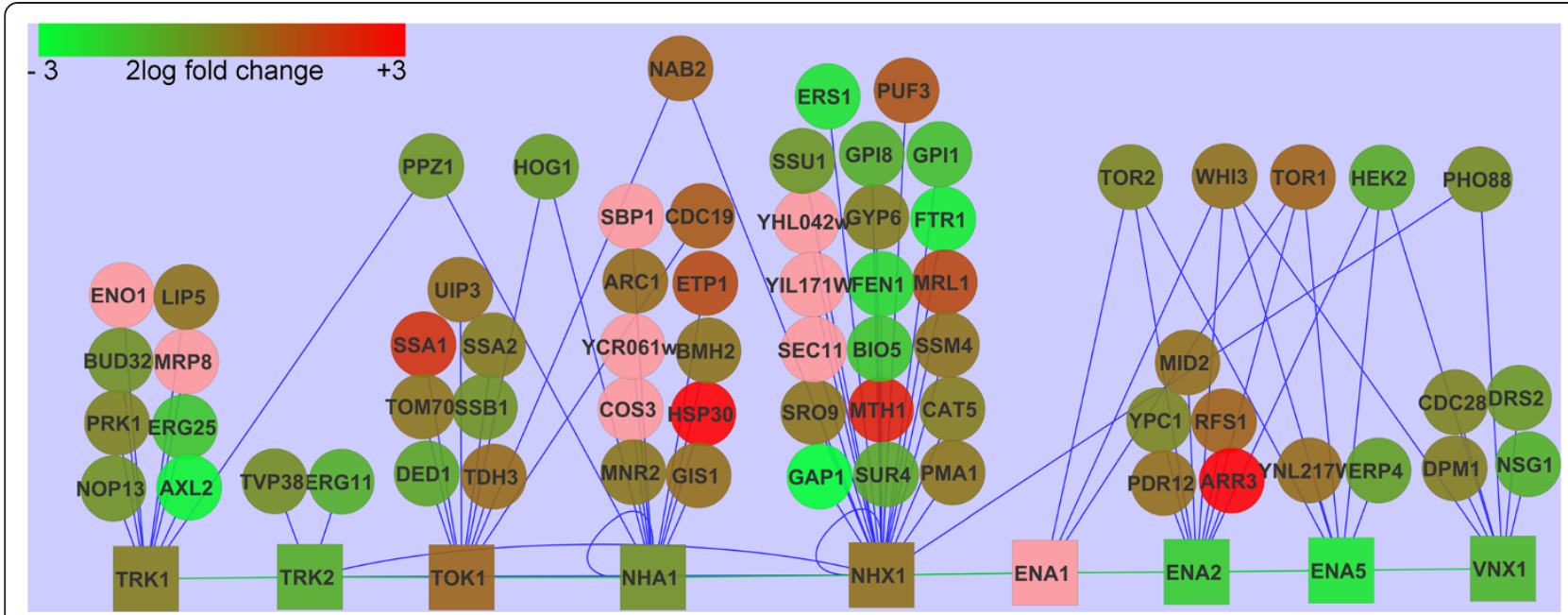

Figure 3 The effect of potassium starvation on the RNA level of a number of S. cerevisiae ion transporters and their binding partners. Protein binding partners (physical interactions) were taken from www.yeastgenome.org. Squares: ion transporters; circles: binding partners. Fold changes in RNA levels are indicated in a color scale, down-regulation in green and up-regulation in red; pink, RNAseq data not available. Protein-protein interactions are shown with blue lines. The figure was made using Cytoscape [33].

the Pho80-Pho85 cyclin-kinase complex [26]. When phosphate is available Pho4 is retained in the cytoplasm, whereas under phosphate limiting conditions it translocates into the nucleus, resulting in expression of genes involved in phosphate uptake. During potassium starvation we observed an increase in nuclear Pho4-GFP (data not shown). The expression of PHO4, PHOSO and PHO85 is only slightly and not significantly affected by potassium starvation (1.14-, 0.58- and 0.94-fold, respectively) [see Additional file 1], suggesting that transcriptional regulation of these genes does not play a role. However, the mechanism of the regulation of Pho4 during potassium starvation still has to be revealed.

Several studies have shown that PHO84 is also transcribed in the opposite direction yielding antisense RNA $[27,28]$. This antisense RNA induces transcriptional silencing of PHO84 via histone deacetylation of the PHO84 promoter when phosphate is available. Our SAGE tag sequencing revealed many tags corresponding to antisense transcripts corresponding to 5665 loci [see Additional file 2] and the levels of many of these tags were affected by potassium starvation, including those of PHO84 [see Additional files 2 and 3]. By applying SAGE tag sequencing, tags corresponding to antisense transcripts were also found in other studies $[29,30]$. However, it has been suggested that spurious synthesis of second-strand cDNA during reverse transcription reactions triggers antisense artifacts [34]. In our studies we performed cDNA synthesis on-the-bead making the formation of artifacts less likely [30]. Furthermore, several studies showed the widespread occurrence of antisense transcription in S. cerevisiae (eg. [35,36]). By RT-PCR using antisense-specific primers during cDNA synthesis we were able to provide additional evidence for antisense transcription of PHO84 (Figure 2). However, the role of antisense transcription in the regulation of $\mathrm{PHO} 4$ during potassium starvation still has to be disclosed.

\section{Methods}

\section{Yeast strains and growth conditions}

In this study the yeast strain BY4741 and strains derived from BY4741 were used, as listed in Table 7. For analysis of growth at low potassium concentrations also a number of homozygous diploid deletion strains in the BY4743 background were used, obtained from Euroscarf (Frankfurt, Germany). Yeast was grown in YPD medium or selective MY medium supplemented, if required, with histidine, leucine, methionine and/or uracil to a final concentration of $20 \mathrm{mg} / \mathrm{L}$ [37]. For cultivation at defined potassium concentrations YNB medium containing very low concentrations of alkali metal cations, developed by the Translucent consortium, was used [20]. Yeast transformations were performed using the LiAc method [38]. Yeast strains carrying plasmids were obtained by transforming parental strains with the appropriate plasmids followed by selection for histidine, and/or uracil prototrophy.

\section{Replacement of promoters by the CYC1 promoter}

To replace the endogenous promoters of YRO2, HSP30, TPO2, PHO84 or ALG9 by the CYC1 promoter a DNA fragment was generated by $\mathrm{PCR}$ on plasmid pYMN10 [40] using the primer combinations YRO2-Fwprom/YRO2-Rev-CYC1, HSP30-Fw-prom/HSP30-Rev-CYC1, TPO2-Fw-prom/TPO2-Rev-CYC1, PHO84-Fw-prom/ PHO84-Rev-CYC1 or ALG9-Fw-prom/ALG9-Rev-CYC1, respectively. The primer sequences are shown in Table 8 . 
Table 7 Yeast strains used in this study

\begin{tabular}{|c|c|c|}
\hline Yeast strain & Genotype & Source/Reference \\
\hline BY4741 & MATa his $3 \Delta 1$ leu $2 \Delta 0$ met15 150 ura $3 \Delta 0$ & Euroscarf, Germany \\
\hline$P_{\text {CYC1:: PHO84 (GG3425) }}$ & 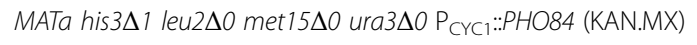 & This study \\
\hline 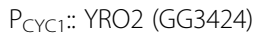 & 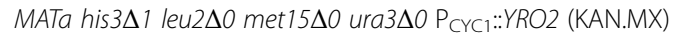 & This study \\
\hline$P_{\text {CYC1:: TPO2 (GG3423) }}$ & 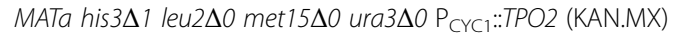 & This study \\
\hline$P_{\text {CYC1: }}$ HSP30 (GG3422) & 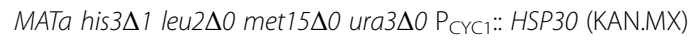 & This study \\
\hline$P_{C Y C 1}::$ ALG9 (GG3426) & 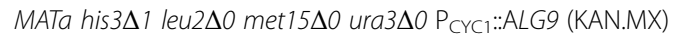 & This study \\
\hline BYT12 & 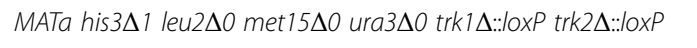 & Hana Sychrova, Prague [39] \\
\hline$\Delta$ pho4 & 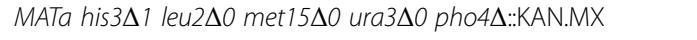 & Euroscarf, Germany \\
\hline
\end{tabular}

These DNA fragments were used to transform BY4741 and transformants were selected on YPD plates containing

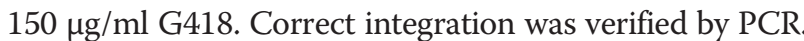

\section{Transcriptome analysis by SAGE-tag sequencing}

Strain BY4741 was grown overnight at $30^{\circ} \mathrm{C}$ in Translucent YNB medium containing $50 \mathrm{mM} \mathrm{KCl}$, supplemented with leucine, histidine, methionine and uracil. This culture was used to inoculate two times $50 \mathrm{ml}$ of supplemented YNB medium containing $50 \mathrm{mM} \mathrm{KCl}$ yielding $\mathrm{A}_{600 \mathrm{~nm}} 0.1$. These cultures were grown to $\mathrm{A}_{600 \mathrm{~nm}} 0.5$ and cells were isolated by centrifugation. Cells from one culture were washed twice with supplemented YNB medium containing $50 \mathrm{mM} \mathrm{KCl}$ and resuspended in $50 \mathrm{ml}$ supplemented YNB medium containing $50 \mathrm{mM} \mathrm{KCl}$. Cells from the other culture were washed twice with supplemented YNB medium lacking $\mathrm{KCl}$ and resuspended in $50 \mathrm{ml}$ supplemented $\mathrm{YNB}$ medium lacking $\mathrm{KCl}$. Both cultures were incubated at $180 \mathrm{rpm}$ at $30^{\circ} \mathrm{C}$. After $60 \mathrm{~min}$ the cultures were poured into plastic tubes and immediately frozen in liquid nitrogen. Prior to RNA isolation, the frozen cultures were thawed on ice and cells were collected by centrifugation and transferred to Eppendorf tubes using ice-cold water. RNA was isolated using the Ambion RiboPure yeast RNA Purification Kit (Life Technologies).

Sequence tags were prepared by the Leiden Genome Technology Center (Leiden, the Netherlands) as described [30]. Briefly, $1 \mu \mathrm{g}$ of total RNA was incubated with oligo-dT beads to capture the polyadenlyated RNA fraction. First- and second-strand cDNA synthesis was performed while the RNA was bound to the beads. While on the beads, samples were digested with NlaIII to retain a cDNA fragment from the most 3' CATG to the poly(A)-tail. Subsequently, the GEX adapter 1 was ligated to the free 5 '-end of the RNA, and a digestion with MmeI was performed, which cuts $17 \mathrm{bp}$ downstream of the CATG site. At this point, the fragments detach from the beads. After dephosphorylation and phenol extraction, the GEX adapter 2 was ligated to the 3'-end of the tag. PCR amplification with 15 cycles using Phusion polymerase was performed with primers complementary to the adapter sequences to enrich the samples for the desired fragments. Sequencing was performed at the Leiden Genome Technology Center on Illumina Hiseq2000 sequencer (Illumina, San Diego, CA, USA). Sequence tags from six samples were bar-coded, mixed and analyzed in a single lane. Obtained sequences were aligned to a virtual tag library obtained by in silico digestion by NlaIII, cutting at 5-CATG-3', of S. cerevisiae sequences corresponding to open reading frames plus $200 \mathrm{bp}$ downstream sequences using the CLC genomic workbench (Aarhus, Denmark). For each open reading frame the number of aligned reads per million was calculated. This was done independently for each biological replicate. Then, the average expression level with standard deviation was determined for each condition ( 0 or $50 \mathrm{mM} \mathrm{KCl}$ ) using the four biological replicates. Statistical analysis was done using the Student's t-test.

The raw sequence data have been deposited in NCBI's Gene Expression Omnibus (GEO) and is accessible through GEO Series accession number GSE57093.

\section{qRT-PCR analysis}

qRT-PCR was performed essentially as described earlier [41]. Yeast strains were cultivated in Translucent YNB medium and RNA was isolated as described above. RNA $(1 \mu \mathrm{g})$ was treated with DNase I (Ambion), according to the recommended protocol, with the addition of $0.5 \mu \mathrm{l}$ RNasin (Promega) per reaction. From each sample, $0.5 \mu \mathrm{g}$ was used for subsequent cDNA synthesis with the oligo-dT primer, using an iScript Select cDNA kit (BioRad). Several dilutions of this cDNA were prepared and qRT-PCR was performed in $25 \mu$ l reaction volumes using a standard PCR reaction mix for Phusion DNA polymerase (Thermo Scientific), with the addition of $1.25 \mu \mathrm{l} 500 \times$ diluted SYBR Green (Life Technologies) in DMSO. PCR efficiency was determined using a series of dilutions of genomic BY4741 DNA. To measure transcript levels of PHO84, YRO2, TPO2, HSP3O and ALG9, primer combinations PHO84-qPCR-Fw/PHO84-qPCRRv, YRO2-qPCR-Fw/YRO2-qPCR-Rv, TPO2-qPCR-Fw/ TPO2-qPCR-Rv, HSP30-qPCR-Fw /HSP30-qPCR-Rv and 
Table 8 Primers used in this study

\begin{tabular}{|c|c|}
\hline Primer & Sequence $\left(5^{\prime}-3^{\prime}\right)$ \\
\hline YRO2-Fw-prom & $\begin{array}{l}\text { TTACGAAAAGTGTCTAGTTGCTCAATGCATATAAA } \\
\text { CTTAATCTA GCTTCGTACGCTGCAGGTCG }\end{array}$ \\
\hline YRO2-Rev-CYC1 & $\begin{array}{l}\text { GGCTTCGTTACCACCTCTITCAATAGTTCAACAT } \\
\text { AATCAGACATTTAGTGTGTGTATTTGTGTTGC }\end{array}$ \\
\hline HSP30-Fw-prom & $\begin{array}{l}\text { CCTTGCGTCTCCCTGCGCGATTITGTTGGCCATT } \\
\text { TTCCAGATCCT GCTTCGTACGCTGCAGGTCG }\end{array}$ \\
\hline HSP30-Rev-CYC1 & $\begin{array}{l}\text { TAAAGCCTCGTTACGATTAAAAAAGCTTGATAGC } \\
\text { GTATCGTTCAT TTAGTGTGTGTATTTGTGTTTGC }\end{array}$ \\
\hline TPO2-Fw-prom & $\begin{array}{l}\text { ACCGATTTCTCGAGATGATTCCATAGCCGTTAAAT } \\
\text { TCATCTCAAA GCTTCGTACGCTGCAGGTCG }\end{array}$ \\
\hline TPO2-Rev-CYC1 & $\begin{array}{l}\text { AGTGTIITGTGAGTTGAATGAAACAACAGATTCTT } \\
\text { GATCACTCATTTAGTGTGTGTATTTGTGTTTGC }\end{array}$ \\
\hline PHO84-Fw-prom & $\begin{array}{l}\text { AATCAGTATTACGCACGTTGGTGCTGTTATAGGCG } \\
\text { CCCTATACGT GCTTCGTACGCTGCAGGTCG }\end{array}$ \\
\hline PHO84-Rev-CYC1 & $\begin{array}{l}\text { ACTTCTITCAGCAACATGAATAGTATCTITATTGAC } \\
\text { GGAACTCAT TTAGTGTGTGTATTTGTGTITGC }\end{array}$ \\
\hline ALG9-Fw-prom & $\begin{array}{l}\text { TाTGATGAGA ACCGTTCTGC GATATTCAGA ACTG } \\
\text { TCAATA CAAGCGCTTCGTACGCTGCAGGTCG }\end{array}$ \\
\hline ALG9-Rev-CYC1 & $\begin{array}{l}\text { AAAATAACAACAGTAATAAACTAATGGTTACCGCC } \\
\text { TTGCAATTCATTAATGTGTGTATTGTGTTGC }\end{array}$ \\
\hline IGPf1 & CGGAATTCAATCAGTATTACGCACGTTGGTGCTG \\
\hline IGPr & CGCGGATCCTCCATTTGGATTGTATTCGTGGAGTT \\
\hline IGpTf & CGGAATTCCGCATTTTACTGAACGAGTCATT \\
\hline IGpTr & CGCGGATCCTCCATATTTGTITTGTGTATTATTT \\
\hline IGpYf3 & CGGAATTCCAATTATAGAATCTGTTGACCAAG \\
\hline IGpYR & CGCGGATCCTCCATTITGATGCTITITITAAAAAA \\
\hline PHO84-qPCR-Fw & ACAACCTTG TTGATCCCAG AA \\
\hline PHO84-qPCR-Rv & TGCTTCATGTTGAAGTTGAGATG \\
\hline YRO2-qPCR-Fw & TGCCATCTCCAGCTTCTTTC \\
\hline YRO2-qPCR-Rv & TCCTCCTCTTCTTGGGCTIT \\
\hline TPO2-qPCR-Fw & TCCATCGACAGTGTTGAGATG \\
\hline TPO2-qPCR-Rv & TGTGGAAATTTGTTATITTTGA \\
\hline HSP30-qPCR-FW & CAACCAGACGGTGAGGCTAT \\
\hline HSP30-qPCR-Rv & TCCGTAGCATGGTGATGAGA \\
\hline ALG9-qPCR-Fw & ACATCGTCGCCCCAATAAAT \\
\hline ALG9-qPCR-Rv & GATTGGCTCCGGTTACGTTGC \\
\hline ACT1-qPCR-Fw & CTGCCGGTATTGACCAAACT \\
\hline ACT1-qPCR-Rv & CGGTGATTTCCTITTGCATT \\
\hline IG-PHO4-Fw-EcoRl & GGGAATTCGTCTCTGTCTAATGCGGTCAC \\
\hline IG-PHO4-Rv-BamHI & GGGGATCCGTTCTCTCAAATCTTCCAACTGATC \\
\hline PHO84-AS-cDNA & CTTCCAGCCCATCTCAACTTC \\
\hline PHO84-SE-cDNA & GAAGTTGAGATGGGCTGGAAG \\
\hline PHO84-AS-PCR-FW & GCATAAAAGCCTCAAAGATGC \\
\hline PHO84-AS-PCR-RV & TGGCAGAGAGATGTGAGGAA \\
\hline
\end{tabular}

ALG9-qPCR-Fw/ALG9-qPCR-Rv, respectively, were used. Transcript levels were normalized against expression of the $A C T 1$, measured using the primer combination
ACT1-qPCR-Fw/ACT1-qPCR-Rv. Experiments were performed on a Chromo4 Real-Time PCR Detection system controlled by the Opticon Monitor 3.1 software (Biorad).

\section{Promoter activity assays}

Promoter activity was determined by fusion of selected promoter regions to the bacterial $ß$-galactosidase gene in plasmid pRUL302 as described [42]. Promoter regions of PHO84, TPO2 and YRO2 were amplified by PCR on chromosomal DNA isolated from BY4741 using the primer combinations IGPf1/IGPr, IGpTf/IGpTr or IGpYf3/ IGpYR, respectively, yielding fragments of 600, 510 and $2141 \mathrm{bp}$, respectively. These fragments were digested with BamH1 and EcoRI and ligated in pRUL302 digested with the same enzymes. These constructs were introduced in yeast and transformants were selected for uracil prototrophy. pRS313[PHO4] (pRUL1334), containing the PHO4 coding region and 578 bp upstream sequences and 500 bp downstream sequences was made by ligating a PCR fragment into pRS313 [43] using the restriction enzymes EcoRI and BamHI. The PHO4 PCR fragment was obtained by PCR using primers IG-PHO4-Fw-EcoRI and IG-PHO4Rv-BamHI with BY4741 genomic DNA as template. All PCR products were analyzed by DNA sequencing.

Yeast strains carrying the various pRUL302 plasmids were grown in Translucent YNB medium supplemented with histidine, methionine and leucine as described above. Yeast cells were isolated from the frozen cultures after thawing and centrifugation and resuspendend in water. $\beta$ Galactosidase activity was measured using the Yeast $\beta$ Galactosidase Assay Kit (Thermo Scientific).

\section{Assays for growth at low potassium concentrations}

Strains were taken from the collection of systematic diploid homozygous deletion strains (Euroscarf, Germany) and were cultivated overnight in Translucent YNB medium supplemented with $50 \mathrm{mM} \mathrm{KCl}$ and histidine, uracil, leucine and methionine. Aliquots of these cultures were centrifuged and cells were washed twice with Translucent YNB medium lacking potassium and subsequently resuspended in Translucent YNB medium lacking potassium till $\mathrm{A}_{620}$ of 0.5 . Ten-fold serial dilutions were made in the same medium and $10 \mu \mathrm{l}$ aliquots were spotted on plates with Translucent YNB medium with different concentrations of $\mathrm{KCl}$ supplemented with histidine, uracil, leucine and methionine. As controls BY4741 and $\Delta$ trk1 1 trk2 in BY4741 were included. Plates were incubated at $30^{\circ} \mathrm{C}$ for 3 days.

\section{Additional files}

Additional file 1: Effect of potassium starvation on RNA levels determined by SAGE tag sequencing. 
Additional file 2: Effect of potassium starvation on antisense transcript levels determined by SAGE tag sequencing.

Additional file 3: Genes of which antisense transcripts are up- or down-regulated more than 2 -fold upon potassium starvation $(P<0.01)$.

\section{Abbreviations}

SAGE: Serial analysis of gene expression; qRT-PCR: Quantitative reverse transcriptase PCR.

\section{Competing interests}

The authors declare that they have no competing interests.

\section{Authors' contributions}

IGA carried out most of the experiments and contributed to writing the manuscript; GPHvH designed the study, performed some experiments and prepared the manuscript. Both authors read and approved the final version of the manuscript.

\section{Acknowledgements}

We would like to thank all members of the Translucent SYSMO project for the stimulating discussions and pleasant collaboration. We thank Henk Buermans (Leiden Genome Technology Center) for SAGE-tag sequencing. Marcel van Verk is acknowledged for his help in using the CLC genomic workbench software, Janneke Teunissen for her help in construction of plasmids and B-galactosidase assays, Rianne Läkamp for her help in qRT-PCR experiments and Stefan Guirten for his help in studying deletion mutants at different potassium concentrations. This study was funded by the Netherlands Organization for Scientific Research (NWO) - Earth and Life Sciences (ALW) (SYSMO) - grants 826.06.004 and 826.09.006.

Received: 2 May 2014 Accepted: 24 November 2014 Published: 29 November 2014

\section{References}

1. Etcheberrigaray R, Ito E, Oka K, Tofel-Grehl B, Gibson GE, Alkon DL: Potassium channel dysfunction in fibroblasts identifies patients with Alzheimer disease. Proc Natl Acad Sci U S A 1993, 90:8209-13.

2. Vitvitsky VM, Garg SK, Keep RF, Albin RL, Banerjee $\mathrm{R}^{\mathrm{Na}^{+}}$and $\mathrm{K}^{+}$ion imbalances in Alzheimer's disease. Biochim Biophys Acta 1822, 2012:1671-81

3. David Y, Cacheaux LP, Ivens S, Lapilover E, Heinemann U, Kaufer D, Friedman A: Astrocytic dysfunction in epileptogenesis: consequence of altered potassium and glutamate homeostasis? J Neurosci 2009, 29:10588-99.

4. Yu SP: Regulation and critical role of potassium homeostasis in apoptosis. Prog Neurobiol 2003, 70:363-386.

5. Shabala S, Cuin TA: Potassium transport and plant salt tolerance. Physiol Plant 2008, 133:651-669.

6. Ariño J, Ramos J, Sychrová H: Alkali metal cation transport and homeostasis in yeasts. Microbiol Mol Biol Rev 2010, 74:95-120

7. Cyert MS, Philpott CC: Regulation of cation balance in Saccharomyces cerevisiae. Genetics 2013, 193:677-713.

8. Ariño J, Aydar E, Drulhe S, Ganser D, Jorrín J, Kahm M, Krause F, Petrezselyova S, Yenush L, Zimmermannova O, van Heusden GPH, Kschischo M, Ludwig J, Palmer C, Ramos J, Sychrova H: Systems biology of monovalent cation homeostasis in yeast: the Translucent contribution. Adv Microb Physiol 2014, 64:1-63.

9. Serrano R, Kielland-Brandt MC, Fink GR: Yeast plasma membrane ATPase is essential for growth and has homology with $\left(\mathrm{Na}^{+}+\mathrm{K}^{+}\right), \mathrm{K}^{+}$- and $\mathrm{Ca}^{2+}$-ATPases. Nature 1986, 319:689-693.

10. Gaber RF, Styles CA, Fink GR: TRK1 encodes a plasma membrane protein required for high-affinity potassium transport in Saccharomyces cerevisiae. Mol Cell Biol 1988, 8:2848-2859.

11. Rodríguez-Navarro: Potassium transport in fungi and plants. Biochim Biophys Acta 2000, 1469:1-30

12. Haro R, Garciadeblas B, Rodriguez-Navarro A: A novel P-type ATPase from yeast involved in sodium transport. FEBS Lett 1991, 291:189-191.

13. Ruiz A, Ariño J: Function and regulation of the Saccharomyces cerevisiae ENA sodium ATPase system. Eukaryot Cell 2007, 6:2175-83.
14. Banuelos MA, Sychrova H, Bleykasten-Grosshans C, Souciet J, Potier S: The Nhal antiporter. Microbiology 1998, 144:2749-2758.

15. Bertl A, Ramos J, Ludwig J, Lichtenberg-Fraté H, Reid J, Bihler H, Calero F, Martínez P, Ljungdahl PO: Characterization of potassium transport in wild-type and isogenic yeast strains carrying all combinations of trk1, trk2 and tok1 null mutations. Mol Microbiol 2003, 47:767-80.

16. Posas F, Chambers JR, Heyman JA, Hoeffler JP, de Nadal E, Arino J: The transcriptional response of yeast to saline stress. J Biol Chem 2000, 275:17249-17255

17. Yale J, Bohnert HJ: Transcript expression in Saccharomyces cerevisiae at high salinity. J Biol Chem 2001, 276:15996-6007.

18. Melamed D, Pnueli L, Arava Y: Yeast translational response to high salinity: global analysis reveals regulation at multiple levels. RNA 2008, 14:1337-1351

19. Capaldi AP, Kaplan T, Liu Y, Habib N, Regev A, Friedman N, O'Shea EK: Structure and function of a transcriptional network activated by the MAPK Hog1. Nat Genet 2008, 40:1300-6.

20. Navarrete C, Petrezsélyová S, Barreto L, Martínez JL, Zahrádka J, Ariño J, Sychrová $\mathrm{H}$, Ramos J: Lack of main $\mathrm{K}^{+}$uptake systems in Saccharomyces cerevisiae cells affects yeast performance in both potassium-sufficient and potassium-limiting conditions. FEMS Yeast Res 2010, 10:508-17.

21. Barreto L, Canadell D, Valverde-Saubí D, Casamayor A, Ariño J: The short-term response of yeast to potassium starvation. Environ Microbiol 2012, 14:3026-42.

22. Robinson MD, Grigull J, Mohammad N, Hughes TR: FunSpec: a web-based cluster interpreter for yeast. BMC Bioinformatics 2002, 3:35

23. Teste M-A, Duquenne M, François JM, Parrou J-L: Validation of reference genes for quantitative expression analysis by real-time RT-PCR in Saccharomyces cerevisiae. BMC Mol Biol 2009, 10:99.

24. Mira NP, Becker JD, Sá-Correia I: Genomic expression program involving the Haa1p-regulon in Saccharomyces cerevisiae response to acetic acid. OMICS 2010, 14:587-601.

25. Oshima Y: The phosphatase system in Saccharomyces cerevisiae. Genes Genet Syst 1997, 72:323-34.

26. O'Neill EM, Kaffman A, Jolly ER, O'Shea EK: Regulation of PHO4 nuclear localization by the PHO80-PHO85 cyclin-CDK complex. Science 1996, 271:209-12.

27. Camblong J, Iglesias N, Fickentscher C, Dieppois G, Stutz F: Antisense RNA stabilization induces transcriptional gene silencing via histone deacetylation in S. cerevisiae. Cell 2007, 131:706-17.

28. Castelnuovo M, Rahman S, Guffanti E, Infantino V, Stutz F, Zenklusen D: Bimodal expression of $\mathrm{PHO} 4$ is modulated by early termination of antisense transcription. Nat Struct Mol Biol 2013, 20:851-8.

29. Quéré $R$, Manchon L, Lejeune $M$, Clément $\mathrm{O}$, Pierrat $\mathrm{F}$, Bonafoux $B$, Commes T, Piquemal D, Marti J: Mining SAGE data allows large-scale, sensitive screening of antisense transcript expression. Nucleic Acids Res 2004, 32:e163.

30. 't Hoen PAC, Ariyurek Y, Thygesen HH, Vreugdenhil E, Vossen RH AM, de Menezes RX, Boer JM, van Ommen G-JB, den Dunnen JT: Deep sequencing-based expression analysis shows major advances in robustness, resolution and inter-lab portability over five microarray platforms. Nucleic Acids Res 2008, 36:e141

31. Gelis S, Curto M, Valledor L, González A, Ariño J, Jorrín J, Ramos J: Adaptation to potassium starvation of wild-type and $\left.\mathrm{K}^{+}\right)$-transport mutant $(t r k 1,2)$ of Saccharomyces cerevisiae: 2-dimensional gel electrophoresis-based proteomic approach. Microbiologyopen 2012, 1:182-93.

32. Hess DC, Lu W, Rabinowitz JD, Botstein D: Ammonium toxicity and potassium limitation in yeast. PLOS Biol 2006, 4:e351.

33. Shannon P, Markiel A, Ozier O, Baliga NS, Wang JT, Ramage D, Amin N, Schwikowski B, Ideker T: Cytoscape: a software environment for integrated models of biomolecular interaction networks. Genome Res 2003, 13:2498-504

34. Perocchi F, Xu Z, Clauder-Münster S, Steinmetz LM: Antisense artifacts in transcriptome microarray experiments are resolved by actinomycin $\mathrm{D}$. Nucleic Acids Res 2007, 35:e128.

35. Xu Z, Wei W, Gagneur J, Perocchi F, Clauder-Münster S, Camblong J, Guffanti E, Stutz F, Huber W, Steinmetz LM: Bidirectional promoters generate pervasive transcription in yeast. Nature 2009, 457:1033-7.

36. Tisseur $M$, Kwapisz M, Morillon A: Pervasive transcription - Lessons from yeast. Biochimie 2011, 93:1889-96. 
37. Zonneveld BJM: Cheap and simple yeast media. J Microbiol Methods 1986, 4:287-291.

38. Gietz RD, Schiestl RH, Willems AR, Woods RA: Studies on the transformation of intact yeast cells by the LiAc / SS-DNA procedure. Yeast 1995, 11:355-360.

39. Petrezselyova S, Zahradka J, Sychrova H: Saccharomyces cerevisiae BY4741 and W303-1A laboratory strains differ in salt tolerance. Fungal Biol 2010, 114:144-150.

40. Janke C, Magiera MM, Rathfelder N, Taxis C, Reber S, Maekawa H, Moreno-Borchart A, Doenges G, Schwob E, Schiebel E, Knop M: A versatile toolbox for PCR-based tagging of yeast genes: new fluorescent proteins, more markers and promoter substitution cassettes. Yeast 2004, 21:947-62.

41. Knip M, Hiemstra S, Sietsma A, Castelein M, de Pater S, Hooykaas P: DAYSLEEPER: a nuclear and vesicular-localized protein that is expressed in proliferating tissues. BMC Plant Biol 2013, 13:211.

42. Ter Linde JJM, Régnacq M, Steensma HY: Transcriptional regulation of YML083c under aerobic and anaerobic conditions. Yeast 2003, 20:439-54

43. Gietz RD, Sugino A: New yeast-Escherichia coli shuttle vectors constructed with in vitro mutagenized yeast genes lacking six-base pair restriction sites. Gene 1988, 74:527-34.

doi:10.1186/1471-2164-15-1040

Cite this article as: Anemaet and van Heusden: Transcriptional response of Saccharomyces cerevisiae to potassium starvation. BMC Genomics 2014 15:1040.

\section{Submit your next manuscript to BioMed Central and take full advantage of:}

- Convenient online submission

- Thorough peer review

- No space constraints or color figure charges

- Immediate publication on acceptance

- Inclusion in PubMed, CAS, Scopus and Google Scholar

- Research which is freely available for redistribution 